\title{
Wine Spoilage Control: Impact of Saccharomycin on Brettanomyces bruxellensis and Its Conjugated Effect with Sulfur Dioxide
}

\author{
Patrícia Branco ${ }^{1,2, *,+}\left(\mathbb{D}\right.$, Rute Coutinho ${ }^{2,+}$, Manuel Malfeito-Ferreira ${ }^{2}$, Catarina Prista $2, *(D)$ \\ and Helena Albergaria ${ }^{1, *}$
}

1 Unit of Bioenergy and Biorefinery, LNEG, Estrada do Paço do Lumiar, 22, 1649-038 Lisboa, Portugal

2 Linking Landscape, Environment, Agriculture and Food (LEAF), Associated Laboratory TERRA, Instituto Superior de Agronomia, University of Lisbon, Tapada da Ajuda, 1349-017 Lisboa, Portugal; anarute.coutinho@gmail.com (R.C.); mmalfeito@isa.ulisboa.pt (M.M.-F.)

* Correspondence: patricia.branco@lneg.pt (P.B.); cprista@isa.ulisboa.pt (C.P.); helena.albergaria@lneg.pt (H.A.); Tel.: +351-210-924-268 (P.B.); +351-213-653-206 (C.P.); +351-210-924-721 (H.A.)

+ Contributed equally to the manuscript.

check for updates

Citation: Branco, P.; Coutinho, R.; Malfeito-Ferreira, M.; Prista, C.; Albergaria, H. Wine Spoilage Control: Impact of Saccharomycin on Brettanomyces bruxellensis and Its Conjugated Effect with Sulfur Dioxide. Microorganisms 2021, 9, 2528. https://doi.org/10.3390/ microorganisms 9122528

Academic Editor: Antonio Bevilacqua

Received: 14 October 2021

Accepted: 5 December 2021

Published: 7 December 2021

Publisher's Note: MDPI stays neutral with regard to jurisdictional claims in published maps and institutional affiliations.

Copyright: (c) 2021 by the authors. Licensee MDPI, Basel, Switzerland. This article is an open access article distributed under the terms and conditions of the Creative Commons Attribution (CC BY) license (https:/ / creativecommons.org/licenses/by/ $4.0 /)$.

\begin{abstract}
The yeast Brettanomyces bruxellensis is one of the most dangerous wine contaminants due to the production of phenolic off-flavors such as 4-ethylphenol. This microbial hazard is regularly tackled by addition of sulfur dioxide $\left(\mathrm{SO}_{2}\right)$. Nevertheless, B. bruxellensis is frequently found at low levels (ca $10^{3}$ cells $/ \mathrm{mL}$ ) in finished wines. Besides, consumers health concerns regarding the use of sulfur dioxide encouraged the search for alternative biocontrol measures. Recently, we found that Saccharomyces cerevisiae secretes a natural biocide (saccharomycin) that inhibits the growth of different B. bruxellensis strains during alcoholic fermentation. Here we investigated the ability of $S$. cerevisiae CCMI 885 to prevent B. bruxellensis ISA 2211 growth and 4-ethylphenol production in synthetic and true grape must fermentations. Results showed that B. bruxellensis growth and 4-ethylphenol production was significantly inhibited in both media, although the effect was more pronounced in synthetic grape must. The natural biocide was added to a simulated wine inoculated with $5 \times 10^{2}$ cells $/ \mathrm{mL}$ of $B$. bruxellensis, which led to loss of culturability and viability $(100 \%$ dead cells at day-12). The conjugated effect of saccharomycin with $\mathrm{SO}_{2}$ was evaluated in simulated wines at 10 , 12,13 and $14 \%(v / v)$ ethanol. Results showed that B. bruxellensis proliferation in wines at 13 and $14 \%$ $(v / v)$ ethanol was completely prevented by addition of $1.0 \mathrm{mg} / \mathrm{mL}$ of saccharomycin with $25 \mathrm{mg} / \mathrm{L}$ of $\mathrm{SO}_{2}$, thus allowing to significantly reduce the $\mathrm{SO}_{2}$ levels commonly used in wines (150-200 mg/L).
\end{abstract}

Keywords: biocontrol; wine-spoilage; biocides; preservatives; wine fermentation

\section{Introduction}

The indigenous microbiota of grape musts includes an immense variety of microorganisms that can grow and ferment sugars [1,2]. Nowadays, most wine fermentations are conducted by selected yeast starters, which are mainly composed of Saccharomyces cerevisiae strains, due to their fast fermentation rates and ability to survive in the harsh environmental conditions of wine [3-5]. Although S. cerevisiae strains usually dominate alcoholic fermentations, some microorganisms such as lactic and acetic acid bacteria and yeasts like Dekkera/Brettanomyces bruxellensis may remain in finished wines and proliferate under certain conditions (e.g., oxygen and/or sugars availability), spoiling the wine [6,7].

Amongst wine contaminants, B. bruxellensis (anamorphic form) and its ascosporeforming type $D$. bruxellensis (teleomorphic form) is considered the most dangerous spoilage microorganism and has been isolated from almost every wine-producing area of the world [8-10]. In red wines, but also in some white wines, B. bruxellensis produces volatile phenols such as 4-ethylphenol and 4-ethylguaiacol, which have characteristic aromas 
described as "barnyard-like" or "horsey-like" [8,11]. Due to the wine spoilage potential of B. bruxellensis, control measures are required to prevent its growth and metabolic activity.

Addition of sulfur dioxide $\left(\mathrm{SO}_{2}\right)$ is the most common preservative practice in winemaking [12] since this chemical is highly toxic to most wine microbial contaminants $[1,13]$ Besides, $\mathrm{SO}_{2}$ has several other properties, acting in wines as an antioxidant [14] antioxidasic [12] and antimicrobial agent $[15,16] . \mathrm{SO}_{2}$ can be added at different stages of the winemaking process: directly to musts, after alcoholic and malolactic fermentation, during wine aging, and at bottling. However, the use of $\mathrm{SO}_{2}$ can be harmful to humans since exposure to sulfites can cause a range of adverse reactions such as dermatitis, urticaria, hypotension, abdominal pain, and diarrhea $[17,18]$. Besides, several studies $[19,20]$ reported the existence of $B$. bruxellensis strains resistant to $\mathrm{SO}_{2}$ at the levels legally allowed in finished wines (150-200 mg/L) [21]. The increasing concerns regarding the excessive use of chemical additives in foodstuffs have raised interest on finding alternative bioprotection methods [22-24].

In recent years, several killer toxins secreted by different yeasts (e.g., Saccharomyces eubayanus and Candida pyralidae) have been suggested as biocontrol agents of B. bruxellensis under winemaking conditions [25,26]. In previous work [27-30], we found that several $S$. cerevisiae strains secrete a natural biocide, which we named saccharomycin, that is active against wine-related non-Saccharomyces yeasts, including B. bruxellensis, as well as lactic acid bacteria. Saccharomycin was found to be composed of antimicrobial peptides (AMPs) derived from the glycolytic enzyme glyceraldehyde-3-phosphate dehydrogenase, and its minimal inhibitory concentration against six B. bruxellensis strains (i.e., ISA 1649, ISA 1700, ISA 1791, ISA 2104, ISA 2116, and ISA 2211) was found to vary between 1-2 mg/mL [28]. Besides, S. cerevisiae CCMI 885 exerted an antagonistic effect against all the above-mentioned B. bruxellensis strains during synthetic grape juice mixed-culture fermentations [29]. In this context, saccharomycin presents itself as a promising biopreservative that might be used in alternative and/or in conjugation with $\mathrm{SO}_{2}$.

The aim of the present work was to evaluate the effectiveness of saccharomycin to prevent $B$. bruxellensis growth and 4-ethylphenol production in wine fermentations, as well as to assess its conjugated effect with $\mathrm{SO}_{2}$ against $B$. bruxellensis proliferation in finished wines, thus allowing to reduce the chemical levels presently used in winemaking.

\section{Materials and Methods}

\subsection{Strains and Inoculums}

In this work we used the Saccharomyces cerevisiae strain CCMI 885 (Culture Collection of Industrial Microorganisms, LNEG, Lisbon, Portugal) and Brettanomyces bruxellensis strain ISA 2211, from Instituto Superior de Agronomia (ISA, University of Lisbon, Portugal). Inoculums of yeast strains were prepared by transferring one YEPD-agar slant into $50 \mathrm{~mL}$ of YEPD medium (10 g/L yeast extract, $20 \mathrm{~g} / \mathrm{L}$ peptone and $20 \mathrm{~g} / \mathrm{L}$ glucose) and incubating the cultures at $30{ }^{\circ} \mathrm{C}$, under agitation (150 rpm) during $16 \mathrm{~h}$ for S. cerevisiae and $72 \mathrm{~h}$ for B. bruxellensis.

\subsection{Growth Media}

Alcoholic fermentations were performed with B. bruxellensis in single-culture and in mixed-culture with $S$. cerevisiae using a Synthetic-Grape Must (SGM) and a True-Grape Must (TGM). The SGM, contained $110 \mathrm{~g} / \mathrm{L}$ of D-glucose (Merck, Darmstadt, Germany), $110 \mathrm{~g} / \mathrm{L}$ of D-fructose (Merck, Darmstadt, Germany), $6.0 \mathrm{~g} / \mathrm{L}$ of tartaric acid (SigmaAldrich, St. Louis, MO, USA), 3.0 g/L malic acid (Sigma-Aldrich, St. Louis, MO, USA), $0.5 \mathrm{~g} / \mathrm{L}$ of citric acid (Sigma-Aldrich, St. Louis, MO, USA), $1.7 \mathrm{~g} / \mathrm{L}$ of yeast nitrogen base w/out amino acids (Difco Laboratories, Franklin Lakes, NJ, USA), $2.0 \mathrm{~g} / \mathrm{L}$ of casamino acids (Merck, Darmstadt, Germany), $0.2 \mathrm{~g} / \mathrm{L} \mathrm{CaCl}_{2}$ (Merck, Darmstadt, Germany), $0.8 \mathrm{~g} / \mathrm{L}$ of arginine-HCl (Sigma-Aldrich, St. Louis, MO, USA), $1.0 \mathrm{~g} / \mathrm{L}$ of proline (Sigma-Aldrich, St. Louis, MO, USA), and $0.1 \mathrm{~g} / \mathrm{L}$ of tryptophan (Sigma-Aldrich, St. Louis, MO, USA), $\mathrm{pH}$ 3.5. The SGM was prepared as described in [31]. The TGM was prepared using 2012 
vintage white grapes (Vitis vinifera L. cv. Alvarinho, Viosinho and Encruzado) collected from an experimental vineyard of Instituto Superior de Agronomia (Lisbon, Portugal). The grapes were frozen at $-70^{\circ} \mathrm{C}$ and stored until the beginning of the assay (approximately 6 months). Grapes were manually crushed, and the obtained grape juice was centrifuged at $10,000 \times g$ for $15 \mathrm{~min}$ (twice) and filtered sequentially through the following pore-size membrane filters (Millipore): $8.0 \mu \mathrm{m} ; 1.2 \mu \mathrm{m} ; 0.45 \mu \mathrm{m}$ (twice). Finally, the cleared juice was filter-sterilized twice again using $0.22 \mu \mathrm{m}$ membrane and the $\mathrm{pH}$ adjusted to 3.5 with ortho-phosphoric acid.

2.3. Synthetic-Grape Must (SGM) and True-Grape Must (TGM) Fermentations Performed with B. bruxellensis in Single-and in Mixed-Culture with S. cerevisiae

SGM and TGM fermentations were performed in $500 \mathrm{~mL}$ flasks containing $300 \mathrm{~mL}$ of each medium (supplemented with $10 \mathrm{mg} / \mathrm{L}$ of $\mathrm{p}$-coumaric acid) that were inoculated with $5 \times 10^{4}$ cells $/ \mathrm{mL}$ of $B$. bruxellensis (strain ISA 2211) in single-culture fermentations and with $5 \times 10^{4}$ cells $/ \mathrm{mL}$ of each yeast species (i.e., of $S$. cerevisiae and B. bruxellensis) in the mixed-culture fermentations. All fermentations (i.e., single- and mixed-culture SGM and TGM fermentations) were carried-out in duplicates and incubated at $25{ }^{\circ} \mathrm{C}$, under slow agitation $(80 \mathrm{rpm})$. Daily samples were taken from each flask to determine yeasts culturability, B. bruxellensis viability, as well as sugars consumption and ethanol and 4-ethylphenol production.

\subsection{Analysis of Growth}

\subsubsection{Culturability}

Culturability of $S$. cerevisiae and B. bruxellensis was determined by the classical plating method. Briefly, $100 \mu \mathrm{L}$ of samples were plated onto YEPD-agar plates, after appropriate dilution (decimal serial dilution method). Plates were incubated at $30^{\circ} \mathrm{C}$ (Vertical Incubator, Infors HT, Anjou, QC, Canada) and the number of Colonies Forming Units (CFU) enumerated after 2-6 days. In the mixed-culture fermentations, CFU counts of B. bruxellensis were obtained on $0.01 \%(w / v)$ cycloheximide YEPD-agar plates and the CFU counts of $S$. cerevisiae as the difference between total CFU counts (corresponding to S. cerevisiae plus B. bruxellensis) on YEPD-agar plates and the CFU counts of B. bruxellensis. The detection limit of the CFU method was 1 CFU/mL for results given in Sections 3.1 and 3.2.1, since $1000 \mu \mathrm{L}$ were directly inoculated onto YEPD-agar plates for samples where no colonies were detected in $100 \mu \mathrm{L}$.

\subsubsection{Viability}

Viability (live/dead) of B. bruxellensis cells in single-culture fermentations was determined by directly applying the Live/Dead staining (LDS) procedure, as described below. For mixed-culture samples, PI-stained cells were then subjected to the Fluorescence In Situ Hybridization (FISH) method, the so-called LDS-FISH method, using the protocol described in [32]. The species-specific FISH-probe used to hybridize B. bruxellensis cells (26S-D.brux. 5.1) was designed by [33] and comprises the following oligonucleotide sequence: 5'-CTTACTCAAATCCCTCCGGT-3'. This FISH-probe was synthesized and labelled with the fluorochrome Fluorescein Isothiocyanate (FITC) at the $5^{\prime}$-end by demand of external services (STAB VIDA, Lisbon, Portugal).

LDS procedure: Briefly, $1 \mathrm{~mL}$ of culture medium was collected daily from single- and mixed-culture fermentations and cells were concentrated by centrifugation at $10,000 \times g$ for $10 \mathrm{~min}$. The pellet was then washed with Bovine Serum Albumin (BSA)-saline solution $(0.25 \% \mathrm{BSA} w / v, 0.1 \% \mathrm{NaCl} w / v)$ by gently pipetting up and down several times. Afterwards, the cell suspension was centrifuged again at $10,000 \times g$ for $10 \mathrm{~min}$ and resuspended in 100-1000 $\mu \mathrm{L}$ of BSA-saline solution, depending on the cellular density. Then, $10 \mu \mathrm{L}$ of Propidium Iodide (PI, supplied by Life Technologies, Carlsbad, CA, USA) working solution $(5 \mu \mathrm{g} / \mathrm{mL})$ was mixed with $100 \mu \mathrm{L}$ of cellular suspension (ca $10^{6}$ cells $\left./ \mathrm{mL}\right)$ and incubated for 10-20 min at room temperature without light. 
LDS-FISH method: After applying the LDS procedure above-described, the PI-stained cellular suspension was centrifuged for $5 \mathrm{~min}$ at $5000 \times g$, the pellet was washed once with $1 \times$ phosphate-buffered saline solution (PBS) and then incubated with $4 \%(v / v)$ of paraformaldehyde for $4 \mathrm{~h}$ at $4{ }^{\circ} \mathrm{C}$ under agitation. Afterwards, fixed cells (approx. $10^{6}$ cells) were centrifuged for $2 \mathrm{~min}$ at $10,000 \times \mathrm{g}$ and hybridized in $45 \mu \mathrm{L}$ of hybridization buffer ( $0.9 \mathrm{M}$ sodium chloride, $0.01 \% \mathrm{w} / v$ sodium dodecyl sulfate, $20 \mathrm{mM}$ Tris- $\mathrm{HCl}$ and $5 \% v / v$ formamide) together with $5 \mu \mathrm{L}$ of FITC labelled probe $(50 \mathrm{ng} / \mu \mathrm{L})$. Incubation was performed at $46{ }^{\circ} \mathrm{C}$ for $3 \mathrm{~h}$. Subsequently, the cell suspension was centrifuged again (5 min at $10,000 \times g)$ and cells resuspended in $100 \mu \mathrm{L}$ of washing solution $(25 \mathrm{mM}$ Tris $/ \mathrm{HCl}$ and $0.5 \mathrm{M} \mathrm{NaCl}$ ). This mixture was incubated for $30 \mathrm{~min}$ at $48{ }^{\circ} \mathrm{C}$. Before enumeration, the previous suspension was again centrifuged, and cells resuspended in $100 \mu \mathrm{L}$ of $1 \times$ PBS.

Quantification of live/dead cells: after applying the LDS or the LDS-FISH treatment, approximately $5 \mu \mathrm{L}$ of each cell suspension was mixed with $5 \mu \mathrm{L}$ of Vecta Shield (Vector Laboratories, Burlingame, CA, USA), spotted onto a Neubauer chamber and cells enumerated using an epifluorescence microscope (Olympus BX-60, Tokyo, Japan). Total cells were visualized in the bright field of the microscope and fluorescent cells in the U-MWB filter. Figure 1 shows LDS-FISH treated cells from a mixed-culture sample, visualized in the bright field (Figure 1a) and in the U-MWB filter (Figure 1b), where green cells correspond to live B. bruxellensis cells (FISH-hybridized cells/non-PI-stained), orange/yellow cells correspond to dead B. bruxellensis cells (FISH-hybridized/PI-stained) and red cells correspond to dead S. cerevisiae cells (not FISH-hybridized/PI-stained).

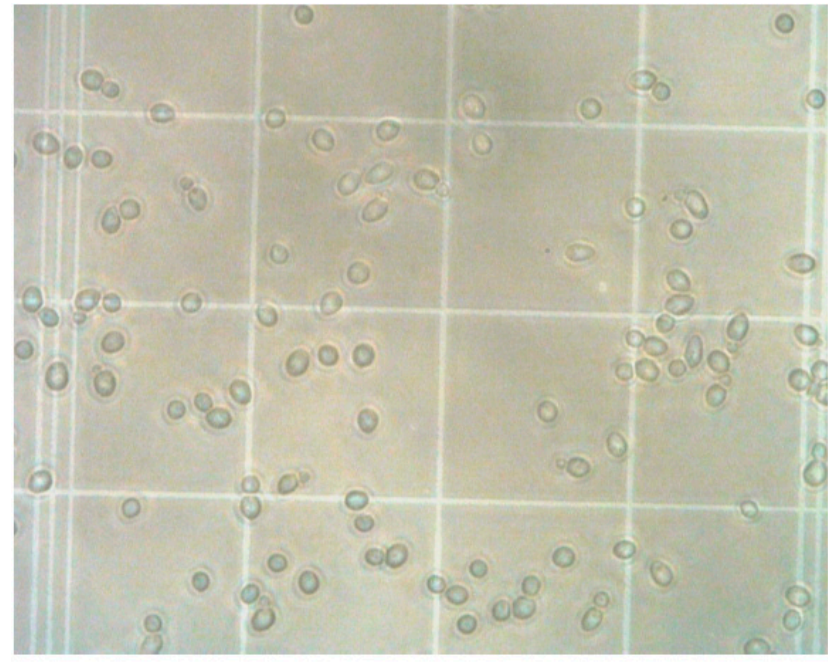

(a)

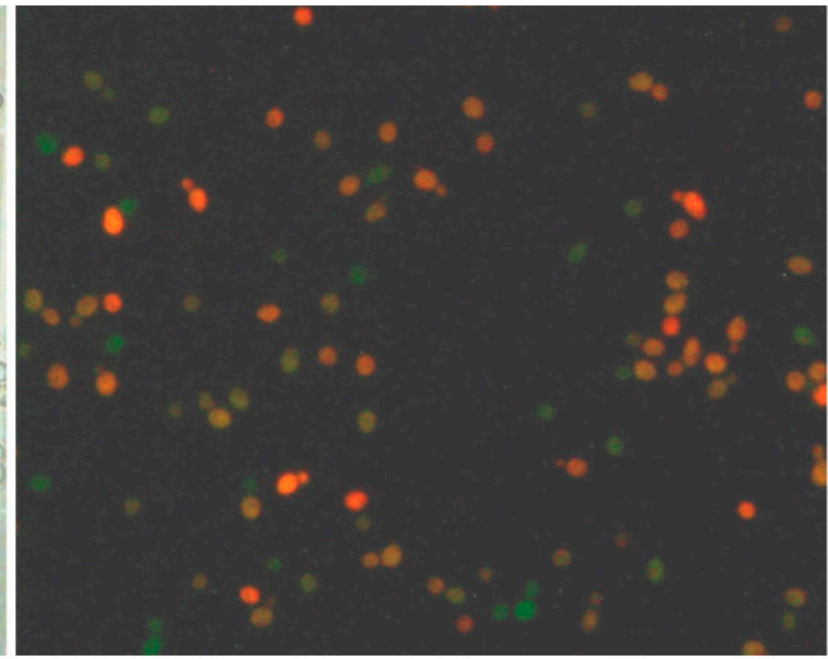

(b)

Figure 1. Microscopic visualization (objective amplification, $40 \times$ ) of cells in a mixed-culture sample after applying of the LDS-FISH procedure. (a) Cells observed in the bright-field; (b) cells observed in the U-MWB filter.

\subsection{Quantification of Sugars and Ethanol by High Performance Liquid Chromatography}

Sugars (glucose and fructose) and ethanol were quantified by High Performance Liquid Chromatography (HPLC), using an HPLC system (Merck Hitachi, Darmstadt, Germany) equipped with a refractive index detector (L-7490, Merck Hitachi, Darmstadt, Germany). Fermentation samples were filtered through $0.22 \mu \mathrm{m}$ Millipore filters (Merck Millipore, Algés, Portugal) and then injected $(20 \mu \mathrm{L})$ in a Sugar-Pack column (Waters Hitachi, Milford, CT, USA). Samples were eluted using as mobile phase CaEDTA (50 mg/L) at $90{ }^{\circ} \mathrm{C}$, with a flow-rate of $0.5 \mathrm{~mL} / \mathrm{min}$. All samples were analysed in duplicate. Glucose, fructose, and ethanol standards at concentrations of 15, 7.5 and $3.75 \mathrm{~g} / \mathrm{L}$ were used to construct calibration curves. 


\subsection{Quantification of 4-Ethylphenol by Gas-Chromatography}

The concentration of 4-ethylphenol (4-EP) produced by B. bruxellensis during singleand mixed-culture SGM and TGM fermentations was quantified by gas-chromatography (GC) using filtered $\left(0.22 \mu \mathrm{m}\right.$ Millipore filters) samples that were first frozen at $-18{ }^{\circ} \mathrm{C}$ in $15 \mathrm{~mL}$ Falcon tubes (Orange Scientific, Braine-L'Alleud, Belgium) and kept frozen until use. 4-EP was quantified using the protocol described in $[9,34]$. The volatile phenol (4-EP) was extracted using ether-hexan from a $5 \mathrm{~mL}$ sample with $\mathrm{pH}$ adjusted to 8.0 with $\mathrm{NaOH}$. The volatile 4-EP was separated by collecting the organic phase of the mixture. The quantification was achieved by gas chromatography using 3,4-dimethylphenol as internal standard. A GC-FID (Varian CP-3800 series, Walnut Creek, CA, USA) with a capillary column Factor-Four (internal diameter $0.25 \mathrm{~mm}$, length $15 \mathrm{~m}$, film thickness $0.25 \mu \mathrm{m}$ ) was used. The injector was run in split less mode, at $230^{\circ} \mathrm{C}$ and the volume of injection was $2 \mu \mathrm{L}$. The detector temperature was set to $250^{\circ} \mathrm{C}$. Hydrogen was used as gas carrier at a flow rate of $0.1 \mathrm{~mL} / \mathrm{min}$. The oven was initially set at $50{ }^{\circ} \mathrm{C}$, then the temperature was raised to $215{ }^{\circ} \mathrm{C}$ at a $10{ }^{\circ} \mathrm{C} / \mathrm{min}$ rate and finally increased up to $250{ }^{\circ} \mathrm{C}$ at a rate of $20^{\circ} \mathrm{C} / \mathrm{min}$. Calibration curves were constructed using 4-EP standards with concentration values ranging from $0-10 \mathrm{mg} / \mathrm{L}$.

\subsection{Production and Purification of Saccharomycin}

The natural biocide (saccharomycin) secreted by S. cerevisiae (strain CCMI 885) was obtained from a SGM-fermentation performed at $25{ }^{\circ} \mathrm{C}$ without agitation for 7 days. The 7 day-old fermented broth was filtered through $0.22 \mu \mathrm{m}$ Millipore membranes (Merck Millipore, Algés, Portugal) and the supernatant was first ultrafiltrated using $10 \mathrm{kDa}$ centrifugal units (Vivaspin 15R, Sartorius, Germany) and then the permeate ( $<10 \mathrm{kDa}$ ) was concentrated (40-fold) in similar centrifugal units equipped with $2 \mathrm{kDa}$ membranes. Finally, $100 \mu \mathrm{L}$ of this concentrated peptidic fraction $(2-10 \mathrm{kDa})$ was fractionated by size-exclusion chromatography using a Superdex-Peptide column (10/300 GL, GE Healthcare, Buckinghamshire, UK). The HPLC system was equipped with an UV-detector (Merck Hitachi, Darmstadt, Germany) and samples were eluted with ammonium acetate $0.1 \mathrm{M}$ at a flow rate of $0.7 \mathrm{~mL} / \mathrm{min}$. The chromatographic pick with retention-time $26-27 \mathrm{~min}$, previously found to contain saccharomycin $[28,30]$ was collected, lyophilized, and stored frozen at $-20^{\circ} \mathrm{C}$ until required.

\subsection{Effectiveness of the Natural Biocide to Prevent B. bruxellensis Growth in Wine}

$300 \mathrm{~mL}$ of TGM were fermented by S. cerevisiae at $25^{\circ} \mathrm{C}$ without agitation for 20 days. Then, the fermented broth was filtered through $0.22 \mu \mathrm{m}$ Millipore filters (Merck Millipore, Algés, Portugal) and the 2-10 kDa peptidic fraction of this cell-free supernatant was ultrafiltrated and concentrated (40-fold) as described in the previous sub-section. The 20-day-old fermented supernatant ( $\mathrm{pH} 3.5$ ), containing $118 \mathrm{~g} / \mathrm{L}$ ethanol and no sugars, was supplemented with $8 \mathrm{~g} / \mathrm{L}$ of fructose to simulate a wine with residual sugars that allow microbial growth, i.e., the "simulated wine". $2 \mathrm{~mL}$ of the above-mentioned peptidic fraction was added to this "simulated wine" that was then inoculated with $5 \times 10^{2} \mathrm{CFU} / \mathrm{mL}$ of B. bruxellensis (strain ISA 2211). A control-assay was performed in the same "simulated wine" but without addition of the 2-10 kDa peptidic fraction, which was used as Control. Culture-assays were incubated at $25^{\circ} \mathrm{C}$ without agitation. Culturability of B. bruxellensis was followed by plate counts (CFU/mL), as described in Section 2.4.1, and viability by the LDS procedure described in Section 2.4.2.

\subsection{Conjugated Effect of Saccharomycin with Sulfur Dioxide $\left(\mathrm{SO}_{2}\right)$ on B. bruxellensis Culturability}

Simulated wines were prepared using the SGM medium ( $\mathrm{pH}$ 3.5) mentioned in Section 2.2, modified in its sugars solution to contain just $4.5 \mathrm{~g} / \mathrm{L}$ of fructose. Ethanol was added to this modified-SGM to obtain simulated wines with $10 \%, 12 \%, 13 \%$ and $14 \%(v / v)$, respectively, with final $\mathrm{pH}$ values of 3.5 . Each simulated wine was artificially contam- 
inated with $5 \times 10^{3}$ cells $/ \mathrm{mL}$ of B. bruxellensis in a final volume of $300 \mu \mathrm{L}$. First, the inhibitory effects of ethanol and $\mathrm{SO}_{2}$ were analyzed in separate, i.e., simulated wines without $\mathrm{SO}_{2}$ but with $10 \%, 12 \%, 13 \%$ and $14 \%(v / v)$ ethanol, respectively, were used to evaluate the ethanol effect on B. bruxellensis growth; simulated wines without ethanol but with 25, 50, 100 and $150 \mathrm{mg} / \mathrm{L}$ of potassium metabisulfite (PMB) (Sigma-Aldrich, Missouri, EUA) (concentrations equivalent to $0.16,0.33,0.66$ and $1 \mathrm{mg} / \mathrm{L}$ of molecular $\mathrm{SO}_{2}$, at $\mathrm{pH}$ 3.5) were used to assess the $\mathrm{SO}_{2}$ effect on $B$. bruxellensis growth. Then, the synergistic effect of $\mathrm{SO}_{2}$ with ethanol was tested using simulated wines at all ethanol levels (i.e., at $10 \%, 12 \%$, $13 \%$ and $14 \%(v / v)$ ethanol), each of them supplemented with 25, 50, 100 and $150 \mathrm{mg} / \mathrm{L}$ of PMB (Sigma-Aldrich, Missouri, EUA). Finally, the conjugated effect of saccharomycin (obtained as described in Section 2.7) with $\mathrm{SO}_{2}$ was evaluated on B. bruxellensis growth using the simulated wines at all ethanol levels (i.e., at 10\%,12\%,13\% and $14 \%(v / v)$ ethanol), each of them supplemented with $0.25,0.5$ and $1 \mathrm{mg} / \mathrm{mL}$ of saccharomycin together with $\mathrm{PMB}$ at 25 and $50 \mathrm{mg} / \mathrm{L}$, respectively. All growth-assays were performed in triplicates in 96 well-microplates and incubated in a Multiskan-GO spectrophotometer (Thermo-Fisher Scientific Inc., Waltham, MA, USA) at $30^{\circ} \mathrm{C}$, under strong agitation. Cell growth was followed by optical density measurements (at $590 \mathrm{~nm}$ ) in a Microplate Reader (Dinex Technologies Inc., Chantilly, VA, USA) and by CFU counts. For CFU counts, $10 \mu \mathrm{L}$ of samples were taken and after appropriate dilution (decimal serial dilution method) $100 \mu \mathrm{L}$ were plated onto YEPD-agar plates, as described in the Section 2.4.1. Whenever colonies could not be detected in agar-plates inoculated with diluted samples, $100 \mu \mathrm{L}$ of sample were directly plated onto YEPD-agar plates. Thus, the detection limit of the CFU method for results presented in Section 3.2.2 was $10 \mathrm{CFU} / \mathrm{mL}$.

\subsection{Statistical Analyses}

The minimum significant difference between results presented in Table 1 and in figures was calculated to allow comparison of mean values, as described by Fry et al. [35]. To check the assumption of equal variances the Levene's test was used and then, one way ANOVA (if the variances were equal) or Welch tests (if the variances were unequal) were applied to determine the significance of the difference between means. The statistical analysis was performed in Microsoft Excel. 


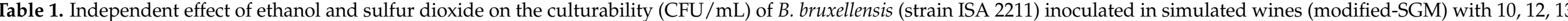

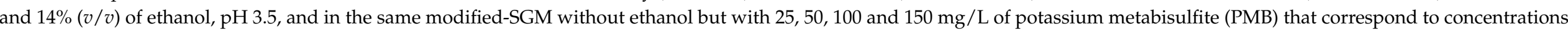

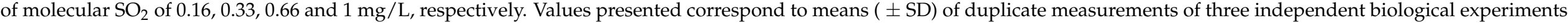
Different letters located before the CFU $/ \mathrm{mL}$ indicate significantly different values $(p<0.05)$.

\begin{tabular}{|c|c|c|c|c|c|c|c|c|c|}
\hline \multicolumn{10}{|c|}{ B. bruxellensis Culturability (CFU/mL) } \\
\hline \multirow{2}{*}{ Time (h) } & \multirow{2}{*}{$\begin{array}{c}\text { Control } \\
-\end{array}$} & \multicolumn{4}{|c|}{ Ethanol $(\% v / v)$} & \multicolumn{4}{|c|}{ PMB (mg/L) } \\
\hline & & 10 & 12 & 13 & 14 & 25 & 50 & 100 & 150 \\
\hline 0 & $\mathrm{a}(5.0 \pm 0.2) \times 10^{3}$ & $\mathrm{a}(5.0 \pm 0.2) \times 10^{3}$ & a $(5.0 \pm 0.2) \times 10^{3}$ & $\mathrm{a}(5.0 \pm 0.2) \times 10^{3}$ & $\mathrm{a}(5.0 \pm 0.2) \times 10^{3}$ & $\mathrm{a}(5.0 \pm 0.2) \times 10^{3}$ & $\mathrm{a}(5.0 \pm 0.2) \times 10^{3}$ & $\mathrm{a}(5.0 \pm 0.2) \times 10^{3}$ & a $(5.0 \pm 0.2) \times 10^{3}$ \\
\hline 24 & $\mathrm{~b}(1.8 \pm 0.2) \times 10^{8}$ & ${ }^{c}(3.3 \pm 0.1) \times 10^{6}$ & ${ }^{c}(2.7 \pm 0.5) \times 10^{6}$ & $\mathrm{~d}(2.4 \pm 0.1) \times 10^{6}$ & $\mathrm{e}(1.6 \pm 0.1) \times 10^{6}$ & ${ }^{\mathrm{f}}(4.0 \pm 0.1) \times 10^{5}$ & ${ }^{\mathrm{f}}(3.7 \pm 0.1) \times 10^{5}$ & $g(3.0 \pm 0.1) \times 10^{4}$ & $\mathrm{~h}(7.0 \pm 1.2) \times 10^{3}$ \\
\hline 48 & $\mathrm{~b}(1.9 \pm 0.2) \times 10^{8}$ & i $(3.4 \pm 0.2) \times 10^{8}$ & $\mathrm{i}(3.0 \pm 0.1) \times 10^{8}$ & i $(2.6 \pm 0.1) \times 10^{8}$ & $\mathrm{~b}(1.9 \pm 0.2) \times 10^{8}$ & $\mathrm{j}(3.5 \pm 0.1) \times 10^{7}$ & $\mathrm{j}(3.9 \pm 0.1) \times 10^{7}$ & $\mathrm{k}(2.9 \pm 0.5) \times 10^{7}$ & ${ }^{1}(1.6 \pm 0.6) \times 10^{7}$ \\
\hline 72 & $\mathrm{i}(3.1 \pm 0.1) \times 10^{8}$ & $\mathrm{i}(3.2 \pm 0.2) \times 10^{8}$ & $\mathrm{i}(3.3 \pm 0.1) \times 10^{8}$ & $\mathrm{i}(3.3 \pm 0.3) \times 10^{8}$ & $\mathrm{i}(2.8 \pm 0.2) \times 10^{8}$ & $\mathrm{i}(3.5 \pm 0.3) \times 10^{8}$ & $\mathrm{i}(3.2 \pm 0.1) \times 10^{8}$ & ${ }^{\mathrm{i}}(2.8 \pm 0.5) \times 10^{8}$ & ${ }^{\mathrm{i}}(2.8 \pm 0.1) \times 10^{8}$ \\
\hline
\end{tabular}




\section{Results}

3.1. Synthetic-Grape Must (SGM) and True-Grape Must (TGM) Fermentations Performed with B. bruxellensis in Single- and in Mixed-Cultures with S. cerevisiae

Metabolic and yeasts growth profiles during SGM fermentations performed with B. bruxellensis in single-culture and in mixed-culture with $S$. cerevisiae are represented in Figure 2. During mixed-culture fermentations (Figure 2a,b) S. cerevisiae increased its cell density from an initial cell density of $5 \times 10^{4} \mathrm{CFU} / \mathrm{mL}$ up to $4 \times 10^{7} \mathrm{CFU} / \mathrm{mL}$ after 3 days, remaining at about $10^{7} \mathrm{CFU} / \mathrm{mL}$ until the end of fermentation (day-10), while B. bruxellensis grew during the first 3 days (from $5 \times 10^{4} \mathrm{CFU} / \mathrm{mL}$ up to $4 \times 10^{6} \mathrm{CFU} / \mathrm{mL}$ ) but then began to die-off, decreasing its culturability in the next 5 days (to $4 \mathrm{CFU} / \mathrm{mL}$ at day-8) (Figure 2a). The loss of culturability of B. bruxellensis during the mixed-culture fermentation was accompanied by an increase of the number of dead cells (PI-stained cells) (Figure 2a) that represented $99 \%$ of the population at day-8. Since the number of culturable cells is extremely low at day- $8(4 \mathrm{CFU} / \mathrm{mL})$ and $99 \%$ of the total cell population was dead, the percentage of viable but non-culturable (VBNC) cells should be less than $1 \%$. Conversely, during the single-culture fermentation (Figure 2c,d) B. bruxellensis culturability increased from $5 \times 10^{4} \mathrm{CFU} / \mathrm{mL}$ at day- 0 up to $4 \times 10^{8} \mathrm{CFU} / \mathrm{mL}$ at day-7, remaining at about $10^{8} \mathrm{CFU} / \mathrm{mL}$ until the end of fermentation (10 days) (Figure 2c). During the singleculture fermentation (Figure 2c,d) B. bruxellensis cell viability (live/dead cells) correlated with its culturability, since the number of viable cells (non-PI-stained cells) remained high throughout fermentation (ranging from $92-98 \%$ during the first 8 days) and decreased to only $65 \%$ at the end of fermentation (day-10) (Figure 2c), when sugars were already completely consumed (Figure 2d). Metabolic profiles (i.e., sugars consumption, and ethanol and 4-ethylphenol production) during the mixed-culture fermentation (Figure $2 \mathrm{~b}$ ) show that sugars (glucose and fructose) were almost completely consumed within the first 5 days ( $4.7 \mathrm{~g} / \mathrm{L}$ of residual fructose), when ethanol attained its highest level $(92 \mathrm{~g} / \mathrm{L})$, and 4-ethylphenol was produced in very low amounts, attaining a maximal concentration of $0.25 \mathrm{mg} / \mathrm{L}$ at day-3. The negligible levels of 4-ethylphenol produced during the mixedculture fermentation (Figure 2b) correlate with the loss of B. bruxellensis viability (Figure 2a). On the contrary, during B. bruxellensis single-culture fermentation (Figure 2c,d) sugars were consumed at a much slower rate (the same amount of sugars was consumed only after 10 days) and ethanol attained its highest concentration $(93 \mathrm{~g} / \mathrm{L})$ after 10 days (Figure $2 \mathrm{~d}$ ), showing that B. bruxellensis metabolism is much slower than that of $S$. cerevisiae. Regarding 4-ethylphenol, results show that this phenolic compound was produced at significantly higher levels in the single-culture fermentation (Figure 2d) attaining $6.44 \mathrm{mg} / \mathrm{L}$ at day-7, what can be explained by the high culturability of $B$. bruxellensis during this fermentation (Figure 2c). Comparing the culturability/viability profiles of B. bruxellensis in single-culture fermentation (Figure 2c) with that in mixed-culture fermentation (Figure 2a), it becomes clear that $S$. cerevisiae exerted a strong antagonistic effect against $B$. bruxellensis growth and 4-ethylphenol production.

To check if the antagonistic effect exerted by $S$. cerevisiae against $B$. bruxellensis would also be effective in TGM, mixed- and single-culture fermentations were performed at the same growth conditions. Yeasts growth and metabolic profiles during the mixed-and singleculture TGM-fermentations are shown in Figure 3. Results show that $S$. cerevisiae exerted an antagonistic effect against B. bruxellensis also in the TGM-fermentation (Figure 3a,b), although the effect was less pronounced than in the SGM-fermentation. In fact, while B. bruxellensis completely lost its culturability and viability within 8 days $(<10 \mathrm{CFU} / \mathrm{mL}$ and $>99 \%$ dead-cells) in the mixed-culture SGM-fermentation (Figure 2a), in the TGMfermentation B. bruxellensis was able to grow in the first 2 days (up to $4.7 \times 10^{5} \mathrm{CFU} / \mathrm{mL}$ ) but then its culturability decreased to $1.7 \times 10^{4} \mathrm{CFU} / \mathrm{mL}$ at day-13, as well as its viability (from $92 \%$ at day-0 to $77 \%$ at day-13) (Figure $3 a$ ). In the single-culture TGM-fermentation (Figure 3c,d), B. bruxellensis was able to grow in the first 6 days, increasing its cell density from $5 \times 10^{4} \mathrm{CFU} / \mathrm{mL}$ at day- 0 to $3 \times 10^{8} \mathrm{CFU} / \mathrm{mL}$ at day- 6 and keeping this value 
$\left(10^{8} \mathrm{CFU} / \mathrm{mL}\right.$ ) for 17 days, while dead cells remained at low numbers (ranging 6-15\% of PI-stained cells) (Figure 3c). Once again, one can conclude that $S$. cerevisiae inhibited $B$. bruxellensis metabolism since a much lower level of 4-ethylphenol $(1.3 \mathrm{mg} / \mathrm{L})$ was produced during the mixed-culture TGM-fermentation (Figure 3b) by comparison with $2.82 \mathrm{mg} / \mathrm{L}$ of 4-ethylphenol produced during the single-culture fermentation (Figure 3d).

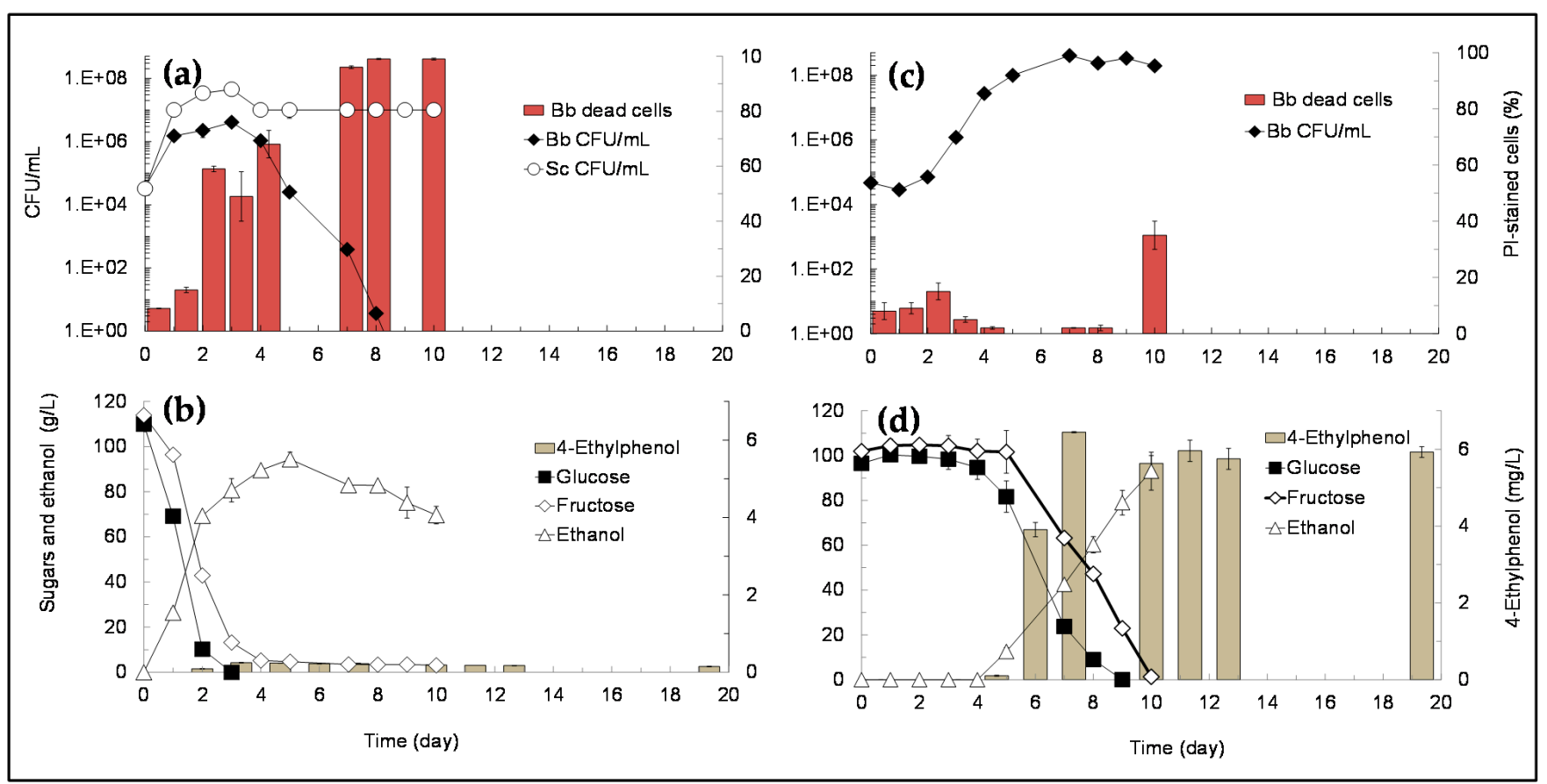

Figure 2. Yeast growth and metabolic profiles during SGM fermentations. (a) Culturability (CFU/mL) of S. cerevisiae (Sc) and B. bruxellensis $(\mathrm{Bb})$, and viability of $\mathrm{Bb}$ (\% dead cells) during mixed-culture fermentation; (b) sugars consumption, and ethanol and 4-ethylphenol production during mixed-culture fermentation; (c) Culturability and viability of Bb during single-culture fermentation; (d) sugars consumption, and ethanol and 4-ethylphenol production during Bb single-culture fermentation. Values presented correspond to means $( \pm S D$ ) of duplicate measurements of two independent biological experiments.

\subsection{Biopreservative Potential of Saccharomycin in Wine}

\subsubsection{Effect of Saccharomycin on B. bruxellensis Culturability and Viability}

To evaluate the effectiveness of the natural biocide (saccharomycin) to prevent B. bruxellensis proliferation in wine, a simulated wine $(118 \mathrm{~g} / \mathrm{L}$ of ethanol and $8 \mathrm{~g} / \mathrm{L}$ of residual fructose, $\mathrm{pH} 3.5$ ) supplemented with $1 \mathrm{mg} / \mathrm{mL}$ of the peptidic fraction containing the natural biocide was artificially contaminated with $5 \times 10^{2}$ cells $/ \mathrm{mL}$ of $B$. bruxellensis. Culturability $(\mathrm{CFU} / \mathrm{mL}$ ) and viability (PI-staining) profiles of B. bruxellensis in the biocideassay and in the control-assay (without biocide) are shown in Figure 4. Results show that while in the control-assay B. bruxellensis was able to grow after the second day of inoculation, attaining $3.3 \times 10^{7} \mathrm{CFU} / \mathrm{mL}$ at day-7, in the biocide-assay B. bruxellensis culturability continuously decreased upon inoculation attaining a cell density of $10 \mathrm{CFU} / \mathrm{mL}$ at day- 9 . The loss of $B$. bruxellensis culturability in the biocide-assay was accompanied by an increase of the percentage of dead cells that reached $85 \%$ at day- 9 and $100 \%$ at day-12, while in the control-assay, viability of B. bruxellensis remained high even after 12 days ( $15 \%$ of cells dead) (Figure 4). 


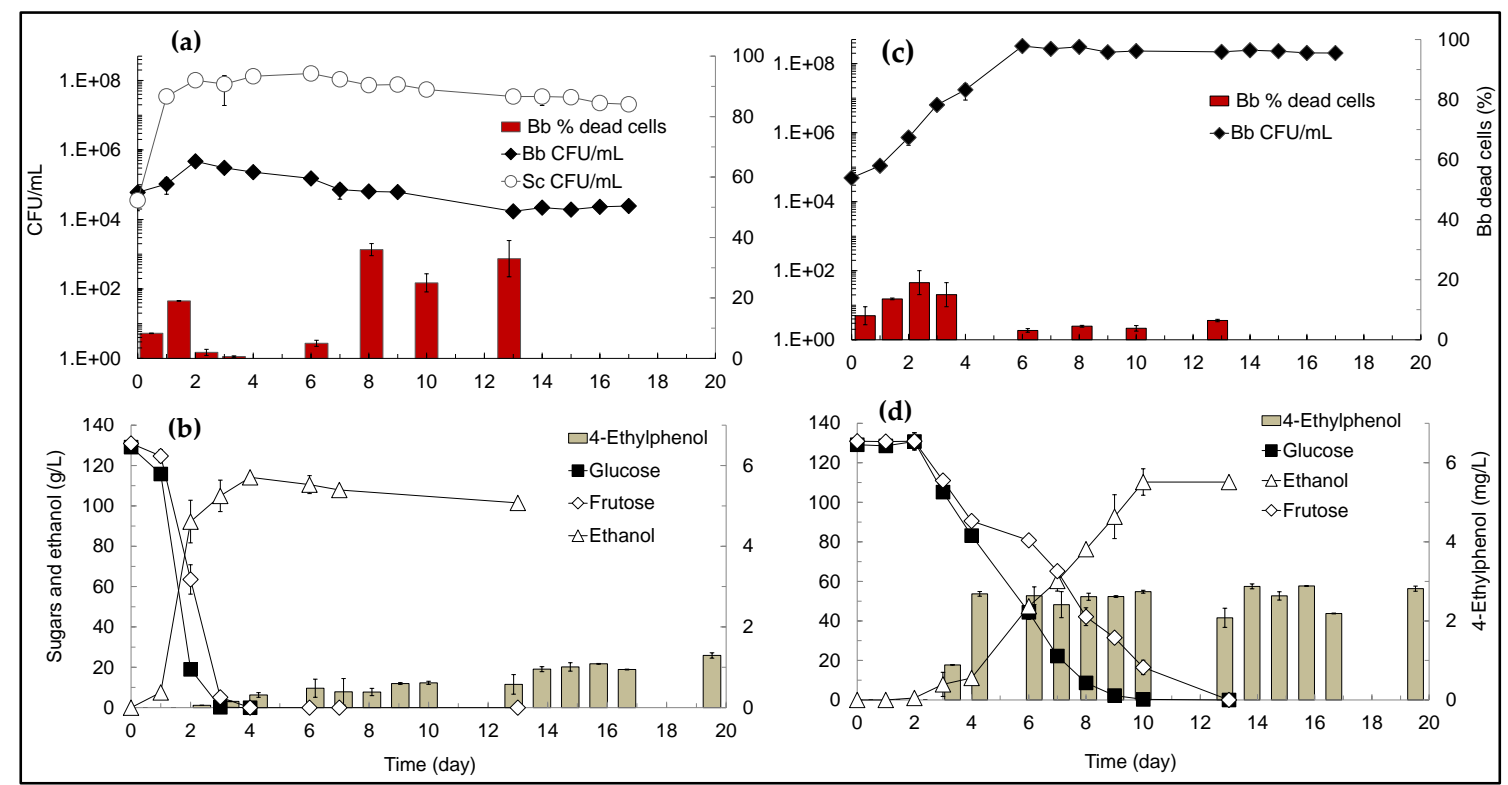

Figure 3. Yeast growth and metabolic profiles during TGM fermentations. (a) Culturability $(\mathrm{CFU} / \mathrm{mL})$ of S. cerevisiae (Sc) and B. bruxellensis $(\mathrm{Bb})$, and viability of $\mathrm{Bb}$ (\% dead cells) during mixed-culture fermentation; (b) sugars consumption, and ethanol and 4-ethylphenol production during mixed-culture fermentation; (c) Culturability and viability of Bb during single-culture fermentation; (d) sugars consumption, and ethanol and 4-ethylphenol production during Bb single-culture fermentation. Values presented correspond to means $( \pm S D)$ of duplicate measurements of two independent biological experiments.

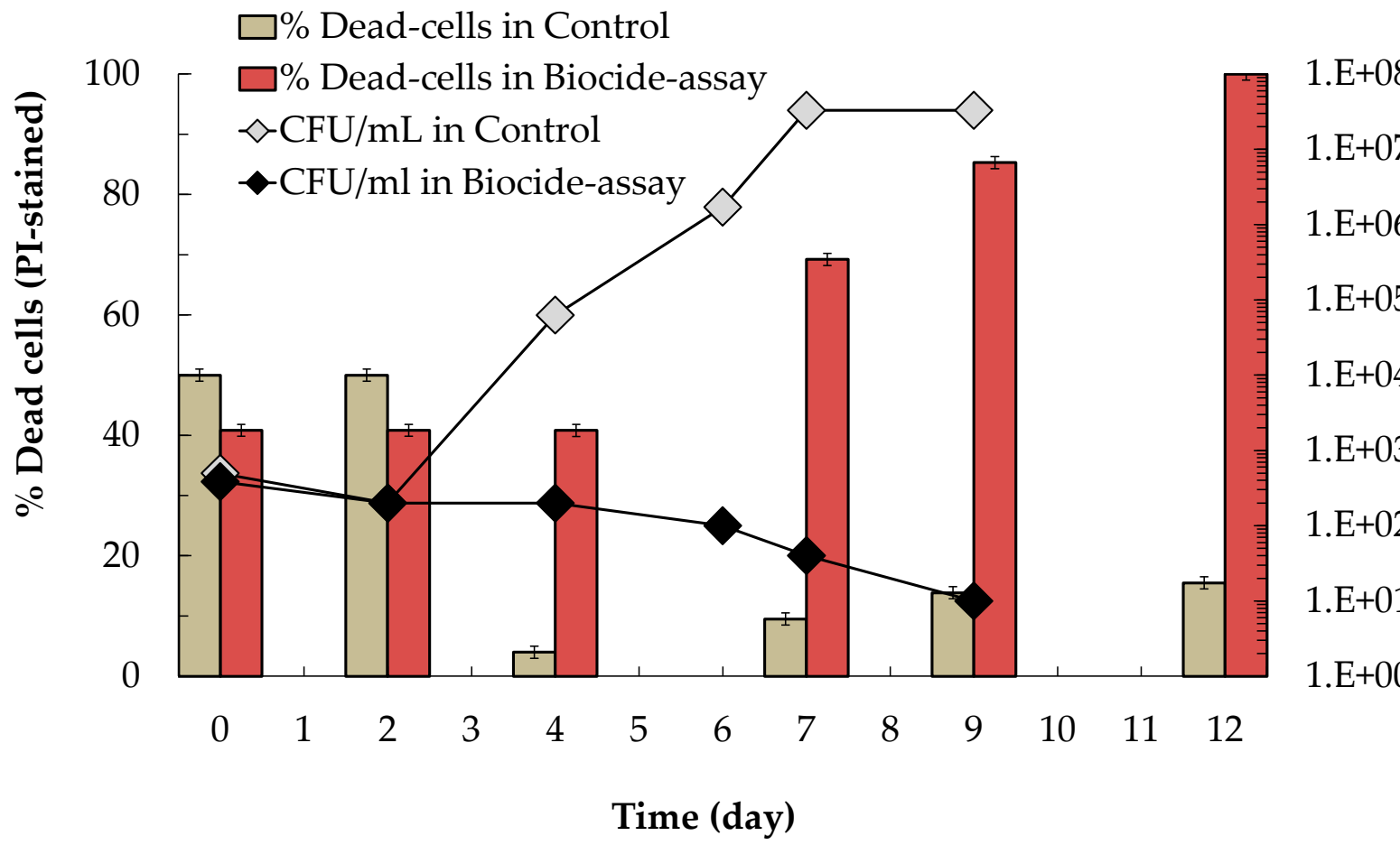

Figure 4. Effect of saccharomycin on the culturability $(\mathrm{CFU} / \mathrm{mL})$ and viability (PI-stained cells) of B. bruxellensis during the biocide assay (simulated wine with $1 \mathrm{mg} / \mathrm{mL}$ of saccharomycin), and in the respective control-assay (simulated wine without saccharomycin). The detection limit of the CFU method was $1 \mathrm{CFU} / \mathrm{mL}$. Values presented correspond to means $( \pm \mathrm{SD})$ of duplicate measurements of two independent biological experiments. 


\subsubsection{Conjugated Effect of Saccharomycin with Sulfur Dioxide $\left(\mathrm{SO}_{2}\right)$}

The single effect of ethanol and potassium metabisulfite (PMB) on B. bruxellensis growth was evaluated in simulated wines ( $\mathrm{pH} 3.5)$, artificially contaminated with $5 \times 10^{3}$ cells $/ \mathrm{mL}$ of B. bruxellensis. Results (Table 1 ) showed that B. bruxellensis was able to grow in the presence of $10 \%, 12 \%, 13 \%$ and $14 \%(\mathrm{v} / \mathrm{v})$ of ethanol, reaching $3 \times 10^{8} \mathrm{CFU} / \mathrm{mL}$ after $72 \mathrm{~h}$. Likewise, $\mathrm{SO}_{2}$ at 25, 50, 100 and $150 \mathrm{mg} / \mathrm{L}$ of PMB was not able to inhibit growth of $B$. bruxellensis in simulated wines without ethanol, with cultures reaching similar cell density levels (i.e., ca $10^{8} \mathrm{CFU} / \mathrm{mL}$ ) after $72 \mathrm{~h}$ (Table 1 ). The combined effect of ethanol $(10 \%, 12 \%, 13 \%$ and $14 \%(v / v))$ with PMB $(25,50,100$ and $150 \mathrm{mg} / \mathrm{L}$ of PMB) was also assessed. Results (Figure 5) revealed that in simulated wines at $10 \%$ and $12 \%(v / v)$ ethanol, B. bruxellensis growth was completely inhibited by 100 and $150 \mathrm{mg} / \mathrm{L}$ of PMB (i.e., 0.66 and $1.0 \mathrm{mg} / \mathrm{mL}$ of molecular $\mathrm{SO}_{2}$ ), respectively (Figure $5 \mathrm{a}, \mathrm{b}$ ), whereas in simulated wines at $13 \%$ and $14 \%(v / v)$ ethanol, B. bruxellensis was only able to proliferate in the presence of $25 \mathrm{mg} / \mathrm{L}$ of PMB $\left(0.16 \mathrm{mg} / \mathrm{mL}\right.$ of molecular $\left.\mathrm{SO}_{2}\right)$ (Figure $\left.5 \mathrm{c}, \mathrm{d}\right)$. Our results are in accordance with the probabilistic model developed by Sturm et al. [36] for B. bruxellensis growth as a function of $\mathrm{pH}$, ethanol and free $\mathrm{SO}_{2}$, which predicts that $B$. bruxellensis is not able to grow in a simulated wine with $50 \mathrm{mg} / \mathrm{L}$ of free $\mathrm{SO}_{2}$ (ca $150 \mathrm{mg} / \mathrm{mL}$ of PMB) when conjugated with ethanol levels between $10 \%$ and $15 \%(v / v)$ and $\mathrm{pH}$ values between 3.3 to 4.1 .

$10 \%$ Ethanol

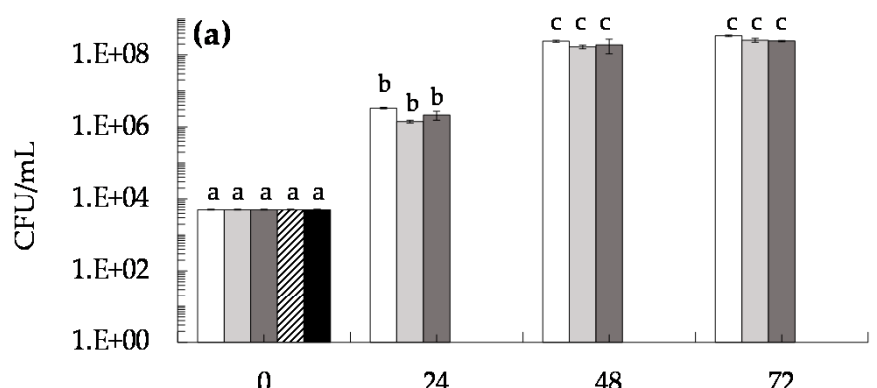

$13 \%$ Ethanol

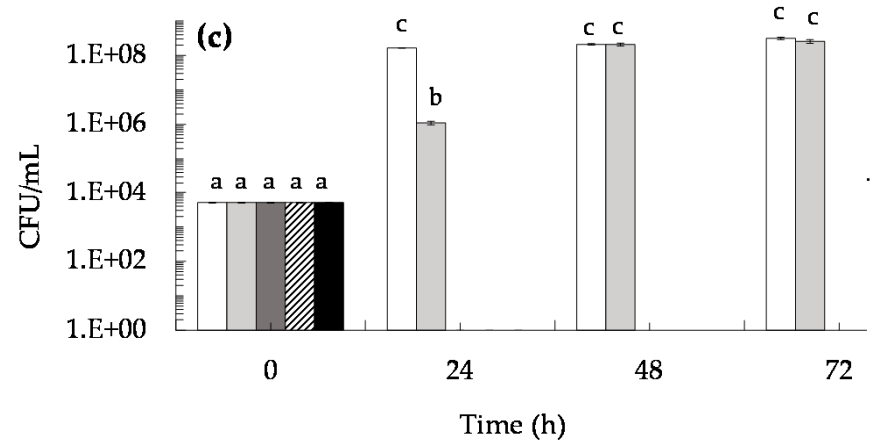

$12 \%$ Ethanol

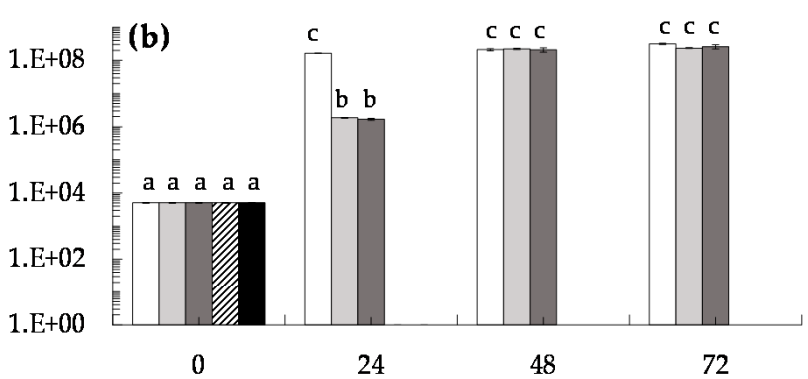

$14 \%$ Ethanol

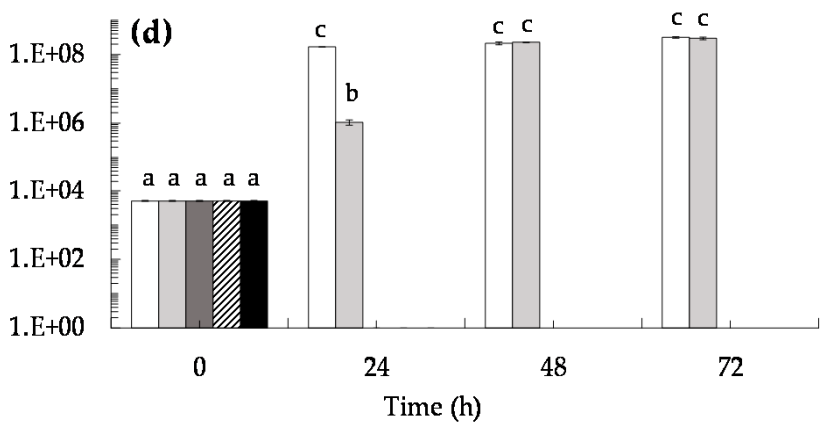

$\square$ Control $\square 25 \mathrm{mg} / \mathrm{L} \mathrm{PMB} \square 50 \mathrm{mg} / \mathrm{L} \mathrm{PMB} 100 \mathrm{mg} / \mathrm{L} \mathrm{PMB} \square 150 \mathrm{mg} / \mathrm{L} \mathrm{PMB}$

Figure 5. Inhibitory effect of potassium metabisulfite (PMB) at 0 (control), 25, 50, 100 and $150 \mathrm{mg} / \mathrm{L}$ PMB on B. bruxellensis culturability $(\mathrm{CFU} / \mathrm{mL})$ in simulated wine inoculated with $5 \times 10^{3} \mathrm{CFU} / \mathrm{mL}$ of B. bruxellensis. (a) Simulated wine with $10 \%(v / v)$ ethanol; (b) simulated wine with $12 \%(v / v)$ ethanol; (c) simulated wine with $13 \%(v / v)$ ethanol; (d) simulated wine with $14 \%(v / v)$ ethanol). Values presented correspond to means $( \pm \mathrm{SD})$ of duplicate measurements of three independent biological experiments. Different letters located over the error bars indicate significantly different values $(p<0.05)$. 
The inhibitory effect of saccharomycin was tested at concentrations of $0.25,0.5$ and $1.0 \mathrm{mg} / \mathrm{mL}$ in simulated wines at $10 \%$ and $12 \%(v / v)$ of ethanol together with $25 \mathrm{mg} / \mathrm{L}$ of PMB (Figure 6a,c) and $50 \mathrm{mg} / \mathrm{L}$ of PMB (Figure 6b,d). Results showed that in both wines inhibition of $B$. bruxellensis growth was only achieved with addition of $1.0 \mathrm{mg} / \mathrm{mL}$ of saccharomycin together with $\mathrm{SO}_{2}$ at both 25 and $50 \mathrm{mg} / \mathrm{mL}$ PMB (Figure 6a-c). However, even addition of $1.0 \mathrm{mg} / \mathrm{mL}$ saccharomycin was not sufficient to induce total loss of $B$. bruxellensis culturability with cultures remaining at ca $10^{3}-10^{4} \mathrm{CFU} / \mathrm{mL}$ after $72 \mathrm{~h}$ (Figure 6a-c).In simulated wines at $13 \%$ and $14 \%(v / v)$ ethanol, the inhibitory effect of saccharomycin (at $0.25,0.5$ and $1.0 \mathrm{mg} / \mathrm{mL}$ ) together with $25 \mathrm{mg} / \mathrm{mL}$ of PMB (Figure $7 \mathrm{a}, \mathrm{b}$ ) revealed that $0.5 \mathrm{mg} / \mathrm{mL}$ of saccharomycin prevented B. bruxellensis growth above $5 \times 10^{3} \mathrm{CFU} / \mathrm{mL}$ in the first $24 \mathrm{~h}$ in the simulated wine at $14 \%(v / v)$ ethanol, while addition of $1.0 \mathrm{mg} / \mathrm{mL}$ saccharomycin induced loss of B. bruxellensis culturability (to less than $10 \mathrm{CFU} / \mathrm{mL}$ ) in both simulated wines (i.e., wines at $13 \%$ and $14 \%(v / v)$ ethanol) (Figure $7 \mathrm{a}, \mathrm{b})$. This demonstrate that $1.0 \mathrm{mg} / \mathrm{mL}$ of saccharomycin together with $25 \mathrm{mg} / \mathrm{L}$ of PMB $(0.16 \mathrm{mg} / \mathrm{mL}$ of molecular $\mathrm{SO}_{2}$ ) is sufficient to reduce $B$. bruxellensis culturability below $10 \mathrm{CFU} / \mathrm{mL}$ within $48 \mathrm{~h}$ in wines at $13 \%$ and $14 \%(v / v)$ ethanol (Figure 7$)$.

$10 \%$ Ethanol+ $25 \mathrm{mg} / \mathrm{L}$ PMB

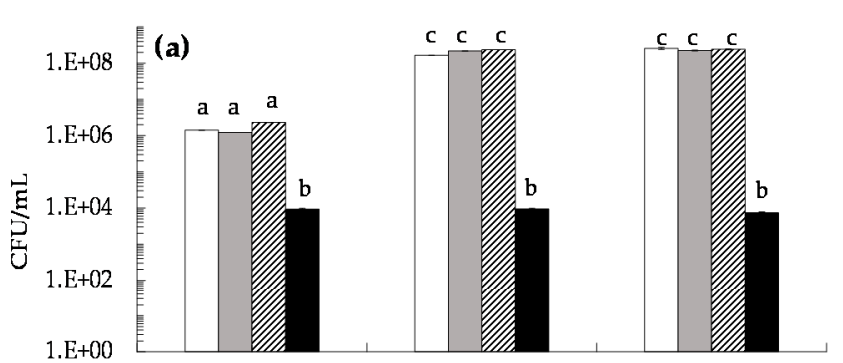

24
48

$12 \%$ Ethanol $25 \mathrm{mg} / \mathrm{L}$ PMB

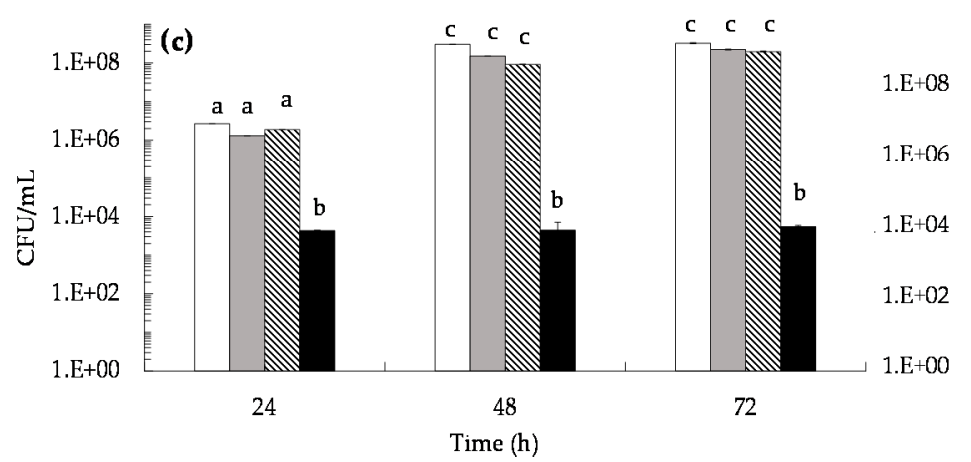

$\square$ Control $\quad \square 0.25 \mathrm{mg} / \mathrm{mL}$ Saccharomycin

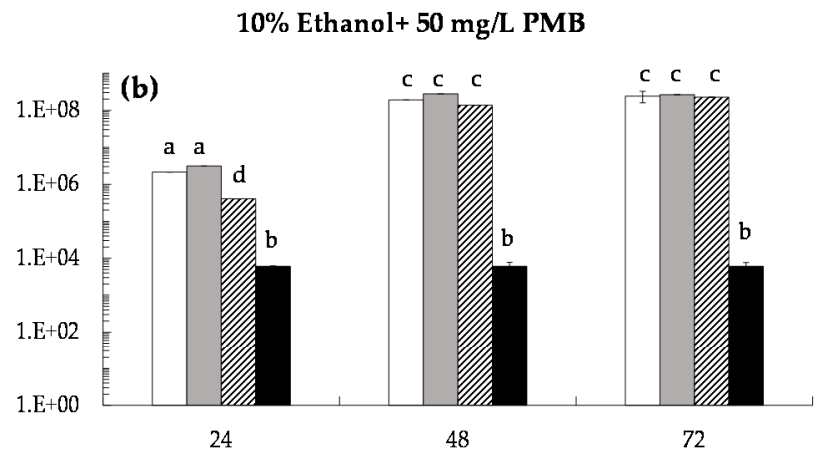

12\% Ethanol+ $50 \mathrm{mg} / \mathrm{L} \mathrm{PMB}$

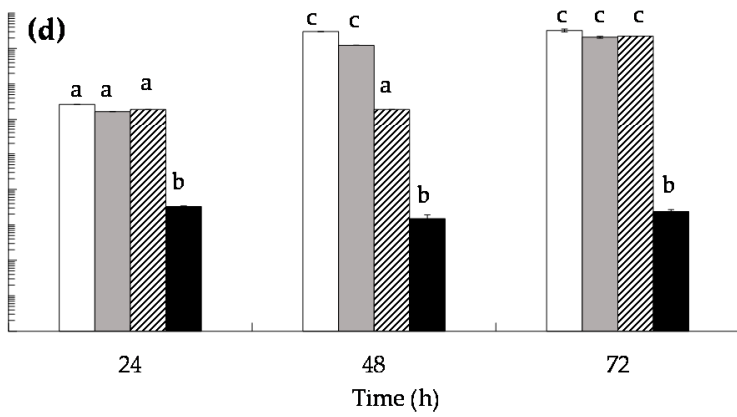

$0.5 \mathrm{mg} / \mathrm{mL}$ Saccharomycin

- $1 \mathrm{mg} / \mathrm{mL}$ Saccharomycin

Figure 6. Conjugated effect of saccharomycin $(0.25,0.5$ and $1.0 \mathrm{mg} / \mathrm{mL})$ with potassium metabisulfite (PMB) on B. bruxellensis culturability $(\mathrm{CFU} / \mathrm{mL})$ in simulated wine inoculated with $5 \times 10^{3} \mathrm{CFU} / \mathrm{mL}$ of B. bruxellensis. (a) Simulated wine at $10 \%$ ethanol and $25 \mathrm{mg} / \mathrm{L} \mathrm{PMB}$; (b) simulated wine at $10 \%$ ethanol with $50 \mathrm{mg} / \mathrm{L} \mathrm{PMB}$; (c) simulated wine at $12 \%$ ethanol with $25 \mathrm{mg} / \mathrm{L} \mathrm{PMB}$; (d) simulated wine at $12 \%$ ethanol with $50 \mathrm{mg} / \mathrm{L}$ PMB. Values presented correspond to means ( \pm SD) of duplicate measurements of three independent biological experiments. Different letters located over the error bars indicate significantly different values $(p<0.05)$. 
13\% Ethanol+ $25 \mathrm{mg} / \mathrm{L} \mathrm{PMB}$

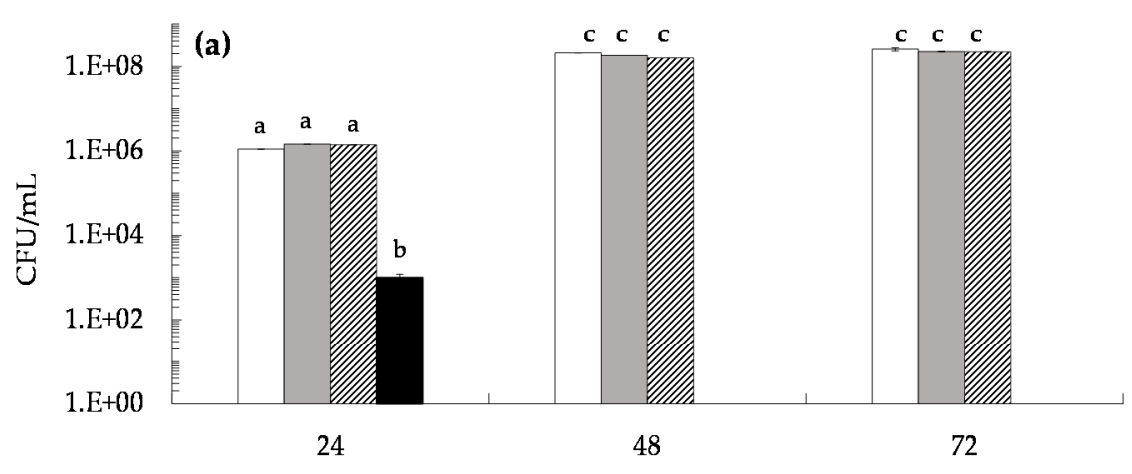

$14 \%$ Ethanol $+25 \mathrm{mg} / \mathrm{L}$ PMB

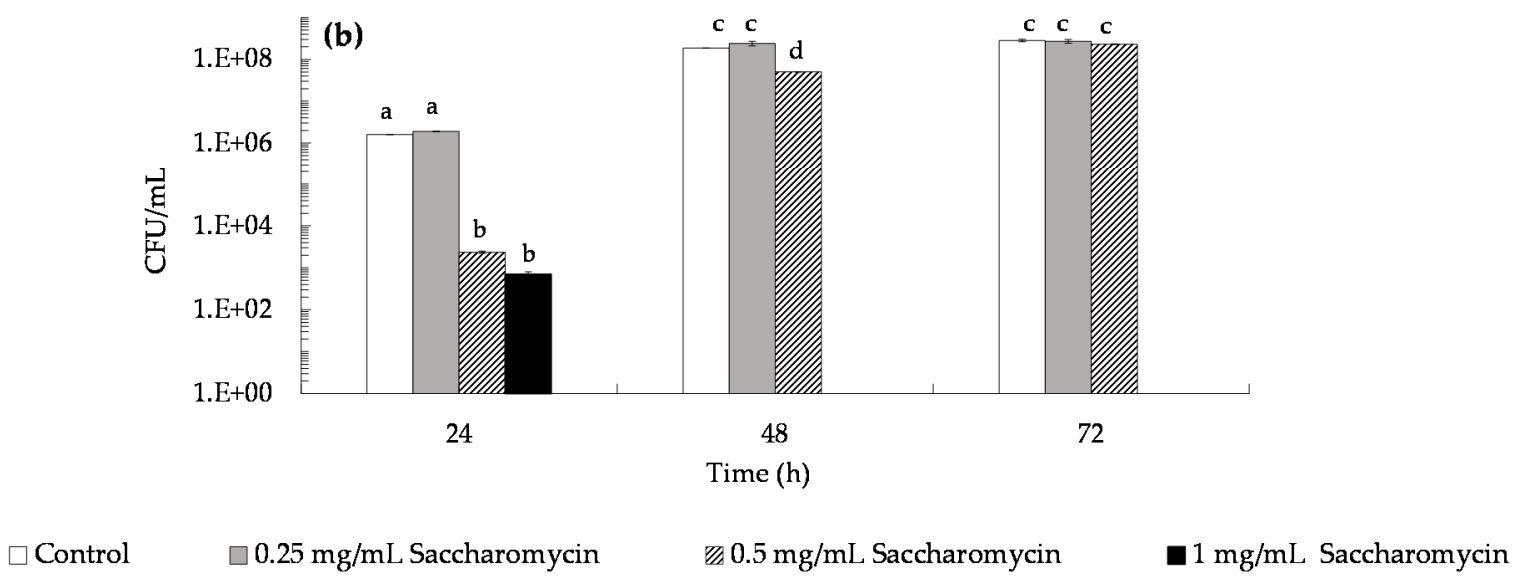

Figure 7. Conjugated effect of saccharomycin $(0.25,0.5$ and $1.0 \mathrm{mg} / \mathrm{mL})$ with $25 \mathrm{mg} / \mathrm{L}$ of potassium metabisulfite (PMB) on B. bruxellensis culturability $(\mathrm{CFU} / \mathrm{mL})$ in simulated wines inoculated with $5 \times 10^{3} \mathrm{CFU} / \mathrm{mL}$ of B. bruxellensis. (a) Simulated wine at $13 \%$ ethanol; (b) simulated wine at $14 \%$ ethanol. Values presented correspond to means ( \pm SD) of duplicate measurements of three independent biological experiments. Different letters located over the error bars indicate significantly different values $(p<0.05)$.

\section{Discussion}

In previous work we found that $S$. cerevisiae secretes a natural biocide (saccharomycin) during alcoholic fermentation that mediates the early death of Hanseniaspora guilliermondii in mixed-culture alcoholic fermentations [28] and inhibits the growth of wine-related nonSaccharomyces yeasts, including B. bruxellensis [28,30]. The effect of saccharomycin was evaluated against the growth of six B. bruxellensis strains (i.e., ISA 1649, ISA 1700, ISA 1791, ISA 2104, ISA 2116 and ISA 2211) in YEPD medium (at pH 3.5) demonstrating to it inhibits all those strains, although the minimal inhibitory concentration varied amongst strains, from 1-2 mg/mL [28]. Besides, S. cerevisiae CCMI 885 also demonstrated to exert an antagonistic effect against all the six B. bruxellensis strains during synthetic grape must (SGM) mixed-culture fermentations [29]. Those results [28-30,37] strongly suggested that saccharomycin is, at least in part, responsible for the antagonism exerted by $S$. cerevisiae against $B$. bruxellensis during mixed-culture alcoholic fermentations. In fact, results obtained in the present work (Figures 2 and 3) support that assumption, since B. bruxellensis rapidly lost its culturability (i.e., from $4.1 \times 10^{6} \mathrm{CFU} / \mathrm{mL}$ at day-3 to $4 \mathrm{CFU} / \mathrm{mL}$ at day-8 in SGM and from $4.7 \times 10^{5} \mathrm{CFU} / \mathrm{mL}$ at day- 3 to $1.7 \times 10^{4} \mathrm{CFU} / \mathrm{mL}$ at day-13 in TGM) during the mixed-culture fermentations (Figures $2 \mathrm{a}$ and $3 \mathrm{a}$ ) but kept its culturability at high levels (ca $10^{8} \mathrm{CFU} / \mathrm{mL}$ ) during the single-culture fermentations (Figures $2 \mathrm{c}$ and $3 \mathrm{c}$ ), namely after total sugars exhaustion (Figure $3 \mathrm{c}$ ). Thus, neither nutrients depletion nor oxygen requirements can explain the early death of B. bruxellensis during mixed-culture fermentations. 
In the previous studies [28-30] alcoholic fermentations were performed in SGM, and not in TGM, and we did not investigate the impact of the antagonistic effect of $S$. cerevisiae on the metabolism of B. bruxellensis, namely on the production of 4-ethylphenol. Thus, in the present work we evaluated and compared the inhibitory effect of $S$. cerevisiae against $B$. bruxellensis growth and 4-ethylphenol production during synthetic- and true-grape must fermentations. Results showed that the antagonistic effect exerted by $S$. cerevisiae on B. bruxellensis growth and 4-ethylphenol production was higher in SGM (Figure 2) than in TGM fermentations (Figure 3). The difference observed might be due to partial inactivation of saccharomycin by its adsorption by proteins in suspension present in truegrape musts [12], amongst other factors such as micronutrients in TGM that may favor $B$. bruxellensis growth. Even though, in TGM-fermentations, the presence of $S$. cerevisiae cells at high cell density (i.e., above $10^{7}$ cells $/ \mathrm{mL}$ ) significantly prevented $B$. bruxellensis growth and reduced the levels of 4-ethyphenol produced (Figure 3a,b), compared with profiles exhibited by B. bruxellensis in single-culture fermentation (Figure 3c,d). However, during mixed-culture TGM fermentations, B. bruxellensis was able to produce $1.3 \mathrm{mg} / \mathrm{L}$ of 4-ethylphenol, which is a concentration higher than the level perceived as negative in red wines, i.e., $0.62 \mathrm{mg} / \mathrm{L}$ [12]. This led us to conclude that to fully prevent spoilage of wine by $B$. bruxellensis strains, it would be necessary to add this natural biopreservative (saccharomycin) to wines. Indeed, our results (Figure 4) showed that addition of $1 \mathrm{mg} / \mathrm{mL}$ of saccharomycin to a simulated wine (at $15 \%(v / v)$ of ethanol), artificially contaminated with $5 \times 10^{2} \mathrm{CFU} / \mathrm{mL}$ of B. bruxellensis, was sufficient to induce total death of B. bruxellensis in 12 days. These results agree well with our previous findings, which showed that in YEPD medium with $30 \mathrm{~g} / \mathrm{L}$ ethanol (at $\mathrm{pH} 3.5$ ) the minimum inhibitory concentrations (MIC) of saccharomycin against several B. bruxellensis strains ranged 1-2 $\mathrm{mg} / \mathrm{mL}$ [28].

According to the European regulation (EC) $n^{\circ} 606 / 2009$, the maximum concentration of sulfur dioxide that can be added to red and white wines (with residual sugars lower than $5 \mathrm{~g} / \mathrm{L}$ and $10-14 \%(v / v)$ ethanol) is $150 \mathrm{mg} / \mathrm{L}$ and $200 \mathrm{mg} / \mathrm{L}$, respectively. However, nowadays, reduction of chemical additives in food manufacturing processes is a societal demand, mainly due to health concerns. In addition, global warming has led to production of wines with increased $\mathrm{pH}$ values, which reduces $\mathrm{SO}_{2}$ antimicrobial efficiency [21]. These concerns are pressing winemakers to search for new preservation practices that can substitute or complement the antimicrobial effect of $\mathrm{SO}_{2}$, allowing them to reduce the levels of $\mathrm{SO}_{2}$ added to wine [22-24]. In the present work, we evaluated the preservation effect of the natural biocide, saccharomycin, against B. bruxellensis, added to simulated wines alone (Figure 4) and in conjugation with $\mathrm{SO}_{2}$ (Figures 6 and 7). First, we evaluated the sensitivity of $B$. bruxellensis ISA 2211 towards $\mathrm{SO}_{2}$ alone in simulated wines at 10,12, 13 and 14\% ethanol. Results (Figure 5) showed that in simulated wines at $10 \%$ and $12 \%(v / v)$ ethanol, B. bruxellensis was only able to grow for $\mathrm{SO}_{2}$ levels lower than $100 \mathrm{mg} / \mathrm{L}$ PMB $\left(0.66 \mathrm{mg} / \mathrm{L}\right.$ of molecular $\left.\mathrm{SO}_{2}\right)$ and in wines with 13 and 14\% $(v / v)$ ethanol for $\mathrm{SO}_{2}$ levels lower than $50 \mathrm{mg} / \mathrm{L} \mathrm{PMB}\left(0.33 \mathrm{mg} / \mathrm{L}\right.$ of molecular $\left.\mathrm{SO}_{2}\right)$. Our results agree with those of Barata et al. [10] who tested the effect of PMB against several strains of B. bruxellensis in red wines, showing that most of the B. bruxellensis strains evaluated, including the strain tested in the present study (i.e., strain ISA 2211), were not able to grow with 100-150 mg/L of PMB. They are also in agreement with results reported by Avramova et al. [38] that classified B. bruxellensis ISA 2211 as sensitive towards $\mathrm{SO}_{2}$ and belonging to the CBS 2499-like group, where most strains are not able to grow with $0.6 \mathrm{mg} / \mathrm{L}$ of molecular $\mathrm{SO}_{2}$, i.e., with ca $100 \mathrm{mg} / \mathrm{L}$ of PMB. Finally, the conjugated effect of saccharomycin $(0.25,0.5$ and $1.0 \mathrm{mg} / \mathrm{mL})$ with $\mathrm{SO}_{2}$ was evaluated in simulated wines with PMB concentrations that allowed growth in each of the simulated wine, i.e., 25 and $50 \mathrm{mg} / \mathrm{L}$ PMB for wines at 10 and $12 \%(v / v)$ ethanol and $25 \mathrm{mg} / \mathrm{L}$ for wines at 13 and $14 \%(v / v)$ ethanol. Results showed that addition of $1 \mathrm{mg} / \mathrm{mL}$ of saccharomycin to wines at $10 \%$ and $12 \%(v / v)$ ethanol, prevented B. bruxellensis growth above the inoculation level (i.e., $5 \times 10^{3} \mathrm{CFU} / \mathrm{mL}$ ) both for wines with 25 and $50 \mathrm{mg} / \mathrm{L}$ PMB (Figure 6). In simulated wines at $13 \%$ and $14 \%(v / v)$ ethanol, addition of $1 \mathrm{mg} / \mathrm{mL}$ of saccharomycin allowed 
to reduce the $\mathrm{SO}_{2}$ levels to $25 \mathrm{mg} / \mathrm{L} \mathrm{PMB} \mathrm{(i.e.,} \mathrm{ca} 0.16 \mathrm{mg} / \mathrm{L}$ molecular $\mathrm{SO}_{2}$ ), induing the loss of B. bruxellensis culturability to less than $10 \mathrm{CFU} / \mathrm{mL}$ (Figure 7).

Thus, our work shows that saccharomycin is a promising wine biopreservative that allows reducing the levels of $\mathrm{SO}_{2}$ usually used in winemaking. However, the present results should be considered as preliminary results since they were obtained at micro-scale growth conditions and not under true wine production conditions. Besides, the impact of other parameters, such as the initial level of B bruxellensis contamination, wine $\mathrm{pH}$ and cells adaptation to ethanol, on the inhibitory efficiency of saccharomycin should also be further assessed.

Author Contributions: P.B., M.M.-F., C.P. and H.A., conceived and designed the research. P.B. and R.C. conducted experiments. P.B., R.C. and H.A. analyzed data. P.B. and H.A. wrote, revised, and edited the manuscript. All authors have read and agreed to the published version of the manuscript.

Funding: This research was financed by FEDER funds through POFC-COMPETE in the scope of project FCOMP-01-0124-FEDER-014055 and by national funds through Fundação para a Ciência e Tecnologia (FCT) in the scope of project PTDC/BII-BIO/31761/2017, and through the research unit, Linking Landscape, Environment, Agriculture and Food (LEAF) (UID/AGR/04129/2013).

Institutional Review Board Statement: Not applicable.

Informed Consent Statement: Not applicable.

Data Availability Statement: All data reported in this study is included in the manuscript.

Acknowledgments: The authors thank to FCT for financial support of this work through the projects FCOMP-01-0124-FEDER-014055 and PTDC/BII-BIO/31761/2017, and through the Research Unit, LEAF. Part of the research was carried out at the Biomass and Bioenergy Research Infrastructure (BBRI)-LISBOA-01-0145-FEDER-022059, supported by Operational Programme for Competitiveness and Internationalization (PORTUGAL2020), by Lisbon Portugal Regional Operational Programme (Lisboa 2020) and by North Portugal Regional Operational Programme (Norte 2020) under the Portugal 2020 Partnership Agreement, through the European Regional Development Fund (ERDF).

Conflicts of Interest: The authors declare they have no conflict of interest.

\section{References}

1. Fleet, G.H.; Heard, G.M. Yeast growth during fermentation. In Wine Microbiology and Biotechnology; Fleet, G.H., Ed.; Harwood Academic Publishers: Chur, Switzerland, 1993; pp. 27-54.

2. Barnett, J.A.; Lichtenthaler, F.W. A history of research on yeasts 3: Emil Fischer Eduard Buchner and their contemporaries, 1880-1900. Yeast 2001, 18, 363-388. [CrossRef]

3. Bauer, F.F.; Pretorius, I.S. Yeast stress response and fermentation efficiency: How to survive the making of wine-A review. S. Afr. J. Enol. Vitic. 2000, 21, 27-51. [CrossRef]

4. Steensels, J.; Daenen, L.; Malcorps, P.; Derdelinckx, G.; Verachtert, H.; Verstrepen, K.J. Brettanomyces yeasts-From spoilage organisms to valuable contributors to industrial fermentations. Int. J. Food Microbiol. 2015, 206, 24-38. [CrossRef]

5. Albergaria, H.; Arneborg, N. Dominance of Saccharomyces cerevisiae in alcoholic fermentation processes: Role of physiological fitness and microbial interactions. Appl. Microbiol. Biotechnol. 2016, 100, 2035-2046. [CrossRef]

6. Fleet, G.H. Yeast interactions and wine flavour. Int. J. Food Microbiol. 2003, 86, 11-22. [CrossRef]

7. Enrique, M.; Marcos, J.F.; Yuste, M.; Martínez, M.; Valles, S.; Manzanares, P. Antimicrobial action of synthetic peptides towards wine spoilage yeasts. Int. J. Food Microbiol. 2007, 118, 318-325. [CrossRef]

8. Fugelsang, K.C. Yeasts. In Wine Microbiology; Fugelsang, K.C., Ed.; The Chapman and Hall Enology Library: New York, NY, USA, 1997; pp. 159-168.

9. Loureiro, V.; Malfeito-Ferreira, M. Spoilage yeasts in the wine industry. Int. J. Food Microbiol. 2003, 86, 23-50. [CrossRef]

10. Barata, A.; Caldeira, J.; Botelheiro, R.; Pagliara, D.; Malfeito-Ferreira, M.; Loureiro, V. Survival patterns of Dekkera bruxellensis in wines and inhibitory effect of sulfur dioxide. Int. J. Food Microbiol. 2008, 121, 201-207. [CrossRef]

11. Caruso, M.; Fiore, C.; Contursi, M.; Salzano, G.; Paparella, A.; Romano, P. Formation of biogenic amines as criteria for the selection of wine yeast. World J. Microbiol. Biotechnol. 2002, 18, 159-163. [CrossRef]

12. Ribéreau-Gayon, P.; Glories, Y.; Maujean, A.; Dubourdieu, D. The Chemistry of Wine Stabilization and Treatments. In Handbook of Enology. The Microbiology of Wine and Vinifications; Ribéreau-Gayon, P., Glories, Y., Maujean, A., Dubourdieu, D., Eds.; John Wiley \& Sons: New Jersey, NJ, USA, 2006; pp. 266-326.

13. Romano, P.; Suzzi, G. Higher alcohol and acetoin production by Zygosaccharomyces wine yeasts. J. Appl. Bacteriol. 1993, 75, 541-545. [CrossRef] 
14. Carrascón, V.; Vallverdú-Queralt, A.; Meudec, E.; Sommerer, N.; Fernandez-Zurbano, P.; Ferreira, V. The kinetics of oxygen and $\mathrm{SO}_{2}$ consumption by red wines. What do they tell about oxidation mechanisms and about changes in wine composition? Food Chemist. 2018, 241, 206214. [CrossRef] [PubMed]

15. Constantí, M.; Reguant, C.; Poblet, M.; Zamora, F.; Mas, A.; Guillamón, J.M. Molecular analysis of yeast population dynamics: Effect of sulphur dioxide and inoculum on must fermentation. Int. J. Food Microbiol. 1998, 41, 169-175. [CrossRef]

16. Albertin, W.; Miot-Sertier, C.; Bely, M.; Marullo, P.; Coulon, J.; Moine, V.; Colonna-Ceccaldi, B.; Masneuf-Pomarede, I. Oenological prefermentation practices strongly impact yeast population dynamics and alcoholic fermentation kinetics in Chardonnay grape must. Int. J. Food Microbiol. 2014, 178, 87-97. [CrossRef]

17. Timbo, B.; Koehler, K.M.; Wolyniak, C.; Klontz, K.C. Sulfites-A food and drug administration review of recalls and reported adverse events. J. Food Prot. 2004, 67, 1806-1811. [CrossRef]

18. Vally, H.; Misso, N.L.A.; Madan, V. Clinical effects of sulphite additives. Clin. Exp. Allergy. 2009, 39, 1643-1651. [CrossRef]

19. Curtin, C.; Kennedy, E.; Henschke, P.A. Genotype-dependent sulphite tolerance of Australian Dekkera (Brettanomyces) bruxellensis wine isolates. Lett. Appl. Microbiol. 2012, 55, 56-61. [CrossRef]

20. Avramova, M.; Grbin, P.; Borneman, A.; Albertin, W.; Masneuf-Pomarède, I.; Cristian, V. Competition experiments between Brettanomyces bruxellensis strains reveal specific adaptation to sulfur dioxide and complex interactions at intraspecies level. Fems. Yeast Res. 2019, 19, foz010. [CrossRef] [PubMed]

21. Pelonnier-Magimel, E.; Windholtz, S.; Masneuf-Pomarède, I.; Barbe, J.C. Sensory characterisation of wines without added sulfites via specific and adapted sensory profile. OENO One 2020, 54, 671-685. [CrossRef]

22. Berbegal, C.; Spano, G.; Fragasso, M.; Grieco, F.; Russo, P.; Capozzi, V. Starter cultures as biocontrol strategy to prevent Brettanomyces bruxellensis proliferation in wine. Appl. Microbiol. Biotechnol. 2018, 102, 569-576. [CrossRef]

23. Mannazzu, I.; Domizio, P.; Carboni, G.; Zara, S.; Zara, G.; Comitini, F.; Budroni, M.; Ciani, M. Yeast killer toxins: From ecological significance to application. Crit. Rev. Biotechnol. 2019, 39, 603-617. [CrossRef]

24. Pinto, L.; Baruzzi, F.; Cocolin, L.; Malfeito-Ferreira, M. Emerging technologies to control Brettanomyces spp. in wine: Recent advances and future trends. Trends Food Sci. Technol. 2020, 99, 88-100. [CrossRef]

25. Mehlomakulu, N.N.; Prior, K.J.; Setati, M.E.; Divol, B. Candida pyralidae killer toxin disrupts the cell wall of Brettanomyces bruxellensis in red grape juice. J. Appl. Microbiol. 2017, 122, 747-758. [CrossRef] [PubMed]

26. Villalba, M.L.; Mazzucco, M.B.; Lopes, C.A.; Ganga, M.A.; Sangorrín, M.P. Purification and characterization of Saccharomyces eubayanus killer toxin: Biocontrol effectiveness against wine spoilage yeasts. Int. J. Food Microbiol. 2020, 331, 108714. [CrossRef]

27. Albergaria, H.; Francisco, D.; Gori, K.; Arneborg, N.; Gírio, F. Saccharomyces cerevisiae CCMI 885 secretes peptides that inhibit the growth of some non-Saccharomyces wine-related strains. Appl. Microbiol. Biotechnol. 2010, 86, 965-972. [CrossRef] [PubMed]

28. Branco, P.; Francisco, D.; Chambon, C.; Hébraud, M.; Arneborg, N.; Almeida, M.G.; Caldeira, J.; Albergaria, H. Identification of novel GAPDH-derived antimicrobial peptides secreted by Saccharomyces cerevisiae and involved in wine microbial interactions. Appl. Microbiol. Biotechnol. 2014, 98, 843-853. [CrossRef]

29. Albergaria, H.; Branco, P.; Francisco, D.; Coutinho, R.; Monteiro, M.; Malfeito-Ferreira, M.; Arneborg, N.; Almeida, M.G.; Caldeira, J. Dominance of Saccharomyces cerevisiae in wine fermentations: Secretion of antimicrobial peptides and microbial interactions. In Proceedings of the 2nd International Conference on Microbial Diversity: Microbial Interactions in Complex Ecosystems, Turin, Italy, 23-25 October 2013; Gallego, J.B., Cardinalli, G., Casella, S., Cocolin, L., Neviani, E., Eds.; Società Italiana di Microbiologia Agraria-Alimentare e Ambientale: Firenze, Italy, 2013; pp. 98-101.

30. Branco, P.; Francisco, D.; Monteiro, M.; Almeida, M.G.; Caldeira, J.; Arneborg, N.; Prista, C.; Albergaria, H. Antimicrobial properties and death-inducing mechanisms of saccharomycin, a biocide secreted by Saccharomyces cerevisiae. Appl. Microbiol. Biotechnol. 2017, 101, 159-171. [CrossRef] [PubMed]

31. Pérez-Nevado, F.; Albergaria, H.; Hogg, T.; Gírio, F. Cellular death of two non-Saccharomyces wine-related yeasts during mixed fermentations with Saccharomyces cerevisiae. Int. J. Food Microbiol. 2006, 108, 336-345. [CrossRef]

32. Branco, P.; Monteiro, M.; Moura, P.; Albergaria, H. Survival rate of wine-related yeasts during alcoholic fermentation assessed by direct live/dead staining combined with fluorescence in situ hybridization. Int. J. Food Microbiol. 2012, 158, 49-57. [CrossRef] [PubMed]

33. Roeder, C.; Koning, H.; Frohlich, J. Species-specific identification of Dekkera / Brettanomyces yeasts by fluorescently labelled DNA probes targeting the 26S rRNA. FEMS Yeast Res. 2007, 6, 1013-1026. [CrossRef]

34. Dias, L.; Pereira-da-Silva, S.; Tavares, M.; Malfeito-Ferreira, M.; Loureiro, V. Factors affecting the production of 4-ethylphenol by the yeast Dekkera bruxellensis in enological conditions. Food Microbiol. 2003, 20, 377-384. [CrossRef]

35. Fry, J.C. One-way analysis of variance. In Biological Data Analysis: A Practical Approach; Fry, J.C., Ed.; Oxford University Press: Oxford, UK, 1993; pp. 1-39.

36. Sturm, M.E.; Arroyo-López, F.N.; Garrido-Fernández, A.; Querol, A.; Mercado, L.A.; Ramirez, M.L.M.; Combina, M. Probabilistic model for the spoilage wine yeast Dekkera bruxellensis as a function of $\mathrm{pH}$, ethanol and free $\mathrm{SO}_{2}$ using time as a dummy variable. Int. J. Food Microbiol. 2014, 170, 83-90. [CrossRef] [PubMed] 
37. Branco, P.; Sabir, F.; Diniz, M.; Carvalho, L.; Albergaria, H.; Prista, C. Biocontrol of Brettanomyces/Dekkera bruxellensis in alcoholic fermentations using saccharomycin-overproducing Saccharomyces cerevisiae strains. Appl. Microbiol. Biotechnol. 2019, 103, 3073-3083. [CrossRef] [PubMed]

38. Avramova, M.; Cibrario, A.; Peltier, E.; Coton, M.; Coton, E.; Schacherer, J.; Spano, G.; Capozzi, V.; Blaiotta, G.; Salin, F.; et al Brettanomyces bruxellensis population survey reveals a diploid-triploid complex structured according to substrate of isolation and geographical distribution. Sci. Rep. 2018, 8, 4136. [CrossRef] [PubMed] 